\title{
A new epigean pseudoscorpion species of Neobisium (Neobisium) (Pseudoscorpiones: Neobisiidae) from the Western Caucasus, Russia
}

\author{
Новый вид наземных можнноскорпионов рода Neobisium \\ (Neobisium) (Pseudoscorpiones: Neobisiidae) \\ с Западного Кавказа, Россия
}

\section{Mahrad Nassirkhani ${ }^{1^{*}}$, Nataly Yu. Snegovaya ${ }^{2}$, Yu.A. Chumachenko ${ }^{3}$ М. Нассирхани ${ }^{*}$, Н.Ю. Снеговая², Ю.А. Чумаченко ${ }^{3}$}

\footnotetext{
${ }^{1}$ Entomology Department, Faculty of Agriculture and Natural Resources, Islamic Azad University, Arak branch, Arak, Iran. E-mail: greenartificialturfgrass@gmail.com

${ }^{2}$ Institute of Zoology of National Academy of Sciences of Azerbaijan, passage 1128, district 504, Baku AZ 1073, Azerbaijan.

${ }^{2}$ Институт зоологии НАН Азербайджана, проезд 1128, квартал 504, Баку AZ 1073, Азербайджан.

${ }^{3}$ Maykop State Technological University, Pervomayskaya St. 191, Maykop, Adygea, 385000 Russia.

${ }^{3}$ Майкопский государственный технологический университет, ул. Первомайская, 191, Майкоп, Адыгея, 385000 Россия.

${ }^{*}$ Corresponding author
}

KEY WORDS: Arachnida, taxonomy, Caucasian State Nature Biosphere Reserve.

КЛЮЧЕВЫЕ СЛОВА: паукообразные, таксономия, Кавказский государственный природный биосферный заповедник.

ABSTRACT. A new pseudoscorpion species, Neobisium (Neobisium) kovalevskayae sp.n., occurring in the beech forest litter, found in the yew, boxwood grove of the Caucasian State Nature Biosphere Reserve is described and its diagnostic characters are illustrated.

How to cite this article: Nassirkhani M., Snegovaya N.Yu., Chumachenko Yu.A. 2019. A new epigean pseudoscorpion species of Neobisium (Neobisium) (Pseudoscorpiones: Neobisiidae) from the Western Caucasus, Russia // Arthropoda Selecta. Vol.28. No.2. P.252256. doi: 10.15298/arthsel. 28.2.07

РЕЗЮМЕ. Описан новый вид ложноскорпионов Neobisium (Neobisium) kovalevskayae sp.n., обитающий в подстилке букового леса, найденный в тисо-самшитовой роще Кавказского государственного природного биосферного заповедника, проиллюстрированы его диагностические признаки.

\section{Introduction}

Hitherto, total of 30 known pseudoscorpion species of the subgenus Neobisium (Neobisium) Chamberlin, 1930 have been recorded for the Middle East, central Asia, and Caucasia [Harvey, 2013; Sezek, Özkan, 2011; Nassirkhani et al., 2018]. The shape of epistome, the carapacal chaetotaxi, the pedipalpal granulation pattern, the trichobothritaxy especially the position of trichobothrium ist, the chelal teeth structure and the morphometric characteristics are the current diagnostic characters using for separating the species belonging to the subgenus Neobisium (Neobisium) Chamberlin, 1930.

Surprisingly, there are some main variations in the specimens attributed to the same species found in the Middle East, central Asia and Caucasia, e.g. the granulation pattern of the pedipalpal femur, and the carapacal chaetotaxy in $N$. (N.) anatolicum Beier, 1949, the shape and size of the chelal teeth in the fixed chelal finger in $N$. (N.) macrodactylum (Daday, 1888), and some morphological and morphometric variations in $N$. (N.) moreoticum Beier, 1932 are some of the observable variations which those have been previously debated by Nassirkhani \& Doustaresharaf [2018] and Nassirkhani \& Mumladze [2019].

Hereon, regardless of the presence of some variations in the carapacal chaetotaxy and the morphometric characteristics of $N$. (N.) validum (L. Koch, 1873), the position of trichobothrium ist is the most significant difference between the specimens reported from different localities around the area. For example, trichbothrium ist is located distinctly distad to middle of the fixed chelal finger, approximately at the same level as st, in the specimens from Georgia and southern Caucasia (see Beier, 1963: fig. 98), whereas it is located slightly distad to middle of the fixed chelal finger, proximad to $s t$, in the specimens from Iran, Turkey and Turkmenistan (see Beier 1949: fig. 3; Ćurčić, 1984: fig. 13; Nassirkhani, Zamani, 2017: fig. 27; Nassirkhani, Doustaresharaf, 2018: fig. 21).

A similar trichobothrial variation can be found in the specimens belonging to $N$. (N.) erythrodactylum (L. Koch, 1873), e.g. trichobothrium ist is located more 
or less distinctly distad to middle of the fixed chelal finger, approximately at the same level as st in the specimens from Azerbaijan (see Ćurčić, 1984: fig. 9), while it is situated approximately in the middle of the fixed chelal finger, slightly proximad to $s t$, in the specimens from Turkey (see Sezek, Özkan, 2008: fig. 4A).

Consequently, it is necessary to reexamine the specimens found in the Middle East, central Asia and Caucasia to provide a revision of the specific levels, and probably revalidate some species or produce some new species or find intraspecific variations within each species!

Based on the presence knowledge regarding to this subgenus, description of a new epigean pseudoscorpion species, Neobisium (N.) kovalevskayae sp.n., from Russia is given in this contribution. Also, its diagnostic characters are illustrated.

\section{Material and methods}

The examined pseudoscorpion specimens were cleared with $60 \%$ solution of lactic acid, and prepared as permanent slides mounted on microscope slides in Hoyer's medium. Microscopical examination and drawings were carried out with an Olympus $\mathrm{CH}-2$ compound microscope. Measurements were made with an ocular graticule. The morphological terminology and mensuration follow Chamberlin [1931], Harvey [1992], Harvey et al. [2012], Judson [2007], and Zaragoza [2008, 2017]. The specimens were deposited in the Collection of Acarology Laboratory, Islamic Azad University of Arak, Iran (IAUA). Measurements are expressed in millimeters and the given ratios are length/width for individual articles and the length/depth for legs.

The following abbreviations are used: Institution: IAUA Islamic Azad University of Arak, Iran. Terms: L — length; W - width; D - depth; mm - millimeter; dat - dorsal accessory tooth. Chaetotaxy: Em - external microseta; Im - internal microseta; $\mathrm{Mm}$ - medial microseta; T, TS tactile seta; GS - galeal seta. Chelal lyrifissures: $f a-$ retrolateral lyrifissure of fixed chelal finger; $f b$ - dorsoretrolateral lyrifissure of fixed chelal finger; $f d-$ dorsodistal lyrifissure of fixed chelal finger; $m a_{1}, m a_{2}, m a_{3}$ retrolateral lyrifissures of movable chelal finger.

Family Neobisiidae Chamberlin, 1930

Genus Neobisium Chamberlin, 1930

Subgenus Neobisium (Neobisium) Chamberlin, 1930

Neobisium (Neobisium) kovalevskayae sp.n.

Figs. 1-10.

MATERIAL EXAMINED. RUSSIA: holotype $\sigma^{7}$, Caucasian State Nature Biosphere Reserve [ $43^{\circ} 32^{\prime} 15.9^{\prime \prime} \mathrm{N} / 39^{\circ} 52^{\prime} 38.57^{\prime \prime} \mathrm{E}$, yew-boxwood grove, beech forest, soil traps, June 2006, Yu. Chumachenko leg. Paratype: $1 O^{7}$ collected with holotype.

ETYMOLOGY. This species is named in honor of Sofia Vasilyevna Kovalevskaya (1850-1891), a Russian mathematician, who was the first woman to obtain a doctorate (in the modern sense) in mathematics, the first woman appointed to a full professorship in Northern Europe, and one of the first women to work for a scientific journal as an editor.

DIAGNOSIS. Neobisium (Neobisium) kovalevskayae sp.n. can be recognized from the other species of the subgenus with the following combination of characters: cara- pace with a minute and blunt epistome, presence of four corneate eyes, movable cheliceral finger with a large median tooth, pedipalpal segments entirely smooth, position of notch on the median side of patella not reaching to middle of the club length, loss of tubercles on pedipalpal femur sides, presence of small tubercle on dorsal face of pedipalpal trochanter, distal half of fixed chelal finger with similar teeth in shape and size, distal fourth of movable chelal finger with triangular teeth and the other teeth rounded and reducing in size to the base, trichobothrial pattern, e.g. position of trichobothrium ist located distinctly distad to middle of fixed chelal finger and distal position of trichobothria et and it in comparison with $t$, each claw of tarsus IV with a small dorsal accessory tooth and morphometric characters, e.g. pedipalpal femur $2.17 \mathrm{~mm}$ long and 5.86-6.02x longer than broad, and movable chelal finger distinctly longer than chelal hand (with pedicel) and somewhat longer than pedipalpal femur.

DESCRIPTION. Large species with relatively elongated extremities.

Carapace (Fig. 1): brown, posterior border pale and not sclerotized; entirely smooth; sub-quadrate, $0.87-0.89 \mathrm{x}$ longer than broad, widest at level of posterior eyes; with 2 pairs of corneate eyes, anterior eyes with more convexity than posteriors, slightly larger than posterior ones, anterior eyes located less than one diameter from anterior margin (distance from anterior margin $0.112-0.117 \mathrm{~mm}$, diameter of anterior eyes $0.130-0.135 \mathrm{~mm}$, separation between eyes $0.050-0.055$ $\mathrm{mm}$, ); with 21-22 setae, anterior margin with 4 setae, preocular microsetae absent, 1 seta situated each side between eyes, posterior margin with 5-6 setae, chaetotaxy (Fig. 1):4:6:6:5-6; transverse furrows absent; epistome (Fig. 1) small, very short, wide and apically rounded (length 0.020 $0.025 \mathrm{~mm}$, width $0.035 \mathrm{~mm}$ ); glandular pores present, 4 on each side in ocular zone and 20-24 scattered along posterior margin; anterolateral corners without protuberances; 2 microlyrifissures situated in ocular zone, and 4 located in posterior margin.

Tergites: brown, I-III darker in colour than IV-XI, all tergites lighter in colour than carapace; smooth; all setae simple; chaetotaxy: 6:4-6:8:9-10:10:10:10:10:10: 2T1TT1T2:T1T2T1T:2.

Sternites: brown, lighter in color than tergites; entirely smooth; without median suture line; genital area with 8-9 setae on anterior operculum, 31-34 setae on posterior operculum, of which 12-13 setae located medially along posterior margin of genital aperture (Fig. 2); internal genital organ with 6 internal setae located each side $(6+6)$; anterior spiracles with 4 and posterior spiracles with 3 short suprastigmal setae; all setae simple; IV-XI uniseriate; IX with 2, X with 4, and XI with 2 tactile setae; chaetotaxy: 8 9:(4)31-34(4):(3)15(3):16:16:16:15-16:5T1T6:4T1T1T1T3: T3T:2.

Pleural membrane: distinctly granulated.

Chelicera: brown; hand with 7 acuminate setae; galea very short, knob-like, with a rounded hyaline convexity (Fig. 3); fixed finger with 23-24 small and close-set teeth reaching to base; movable finger with $16-18$ teeth reaching proximad to galeal seta, with1 median large tooth (Fig. 3); galeal setae situated distad to middle $(\mathrm{GS}=0.69)$; serrula interior with 20-23 and exterior with 30 blades; rallum with 8 blades, 6 posterior blades simple, smooth and acuminate, 2 anterior blades long and denticulate, proximalmost blade smallest, distalmost blade more or less isolated and located on a high hyaline promontory (Fig. 4).

Pedipalps: reddish brown, darker in colour than carapace; entirely smooth (Figs. 5-7); coxa including manduca- 


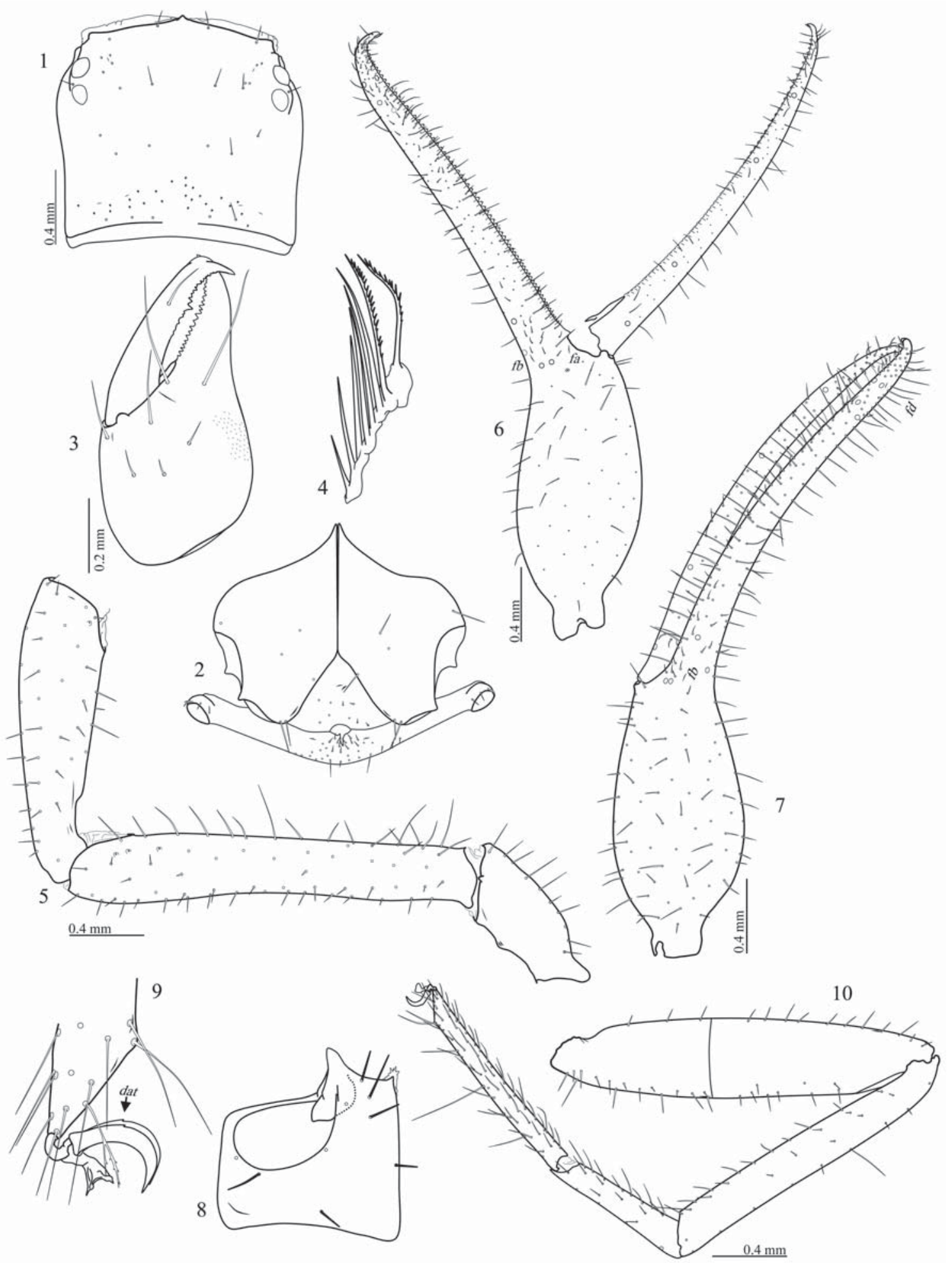

Figs 1-10. Neobisium (Neobisium) kovalevskayae sp.n., holotype $0^{7}: 1-$ carapace, dorsal view; 2 - coxae IV and sternites II-III, ventral view; 3 - left chelicera, dorsal view; 4 - rallum; 5 - left pedipalp (chela omitted), dorsal view; 6 - right chelal hand, retrolateral view; 7 - left chela, dorsal view; 8 - right coxa I, ventral view; 9 - distal part of tarsus of right leg IV, retrolateral view; 10 - right leg IV (trochanter omitted), retrolateral view. See Material and methods for abbreviations.

Рис.1-10. Neobisium (Neobisium) kovalevskayae sp.n., голотип O’: 1 - карапакс, дорсально; 2 - тазики IV и стерниты II-III, вентрально; 3 - левая хелицера, дорсально; 4 - раллум; 5 - левая педипальпа (без хелы), дорсально; 6 - рука правой хелы, ретролатерально; 7 - левая хела, дорсально; 8 - правый тазик I, вентрально; 9 - дистальная часть лапки правой ноги IV, ретролатерально; 10 - правая нога IV (без вертлуга), ретролатерально. Сокращения см. в разделе Material and methods. 


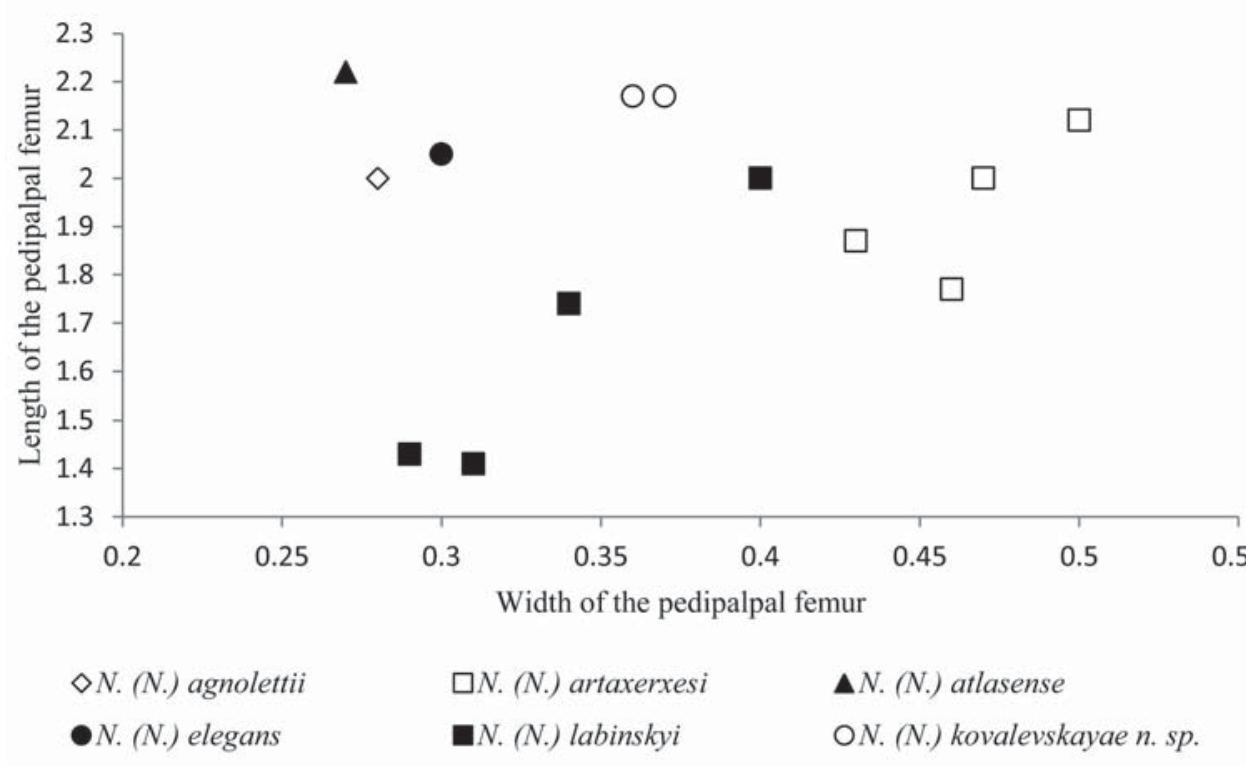

Fig. 11. Pediplalpal femur size difference in $N .(N$.$) kovalevskayae sp.n., Neobisium (N.) agnolettii Beier, 1973, N. (N.) artaxerxesi$ Nassirkhani et al., 2018, N. (N.) atlasense Leclerc, 1989, N. (N.) elegans Beier, 1939, and N. (N.) labinskyi Beier, 1937.

Рис. 11. Различия в размере бедра педипальпы у N. (N.) kovalevskayae sp.n., Neobisium (N.) agnolettii Beier, 1973, N. (N.) artaxerxesi Nassirkhani et al., 2018, N. (N.) atlasense Leclerc, 1989, N. (N.) elegans Beier, 1939 и N. (N.) labinskyi Beier, 1937.

tory process with 13 setae, longest seta located at the base of manducatory process, manducatory process with 5 acuminate setae; trochanter with small but prominent dorsal ridge, L/W 2.47; femur without distinct pedicel, without tubercles on retrolateral/prolateral margins, setae without enlarged alveoli fallen! (Fig. 5), L/W 5.86-6.02; patella with short and stout pedicel $(\mathrm{L}=0.39-0.41 \mathrm{~mm})$; patella distinctly shorter and wider than femur, notch on the median side reaching to about distal third of the club length, with 4 lyrifissures situated basally and one lyrifissure located distally, L/W 3.83-3.87; chela (with pedicel) L/W 5.11-5.14; chela (without pedicel) L/W 4.82-4.85; chelal setae simple; movable finger 1.49-1.50x longer than hand (with pedicel); chelal hand (with pedicel) L/W 2.15-2.17; chelal hand (without pedicel) L/W 1.86-1.88; 10-11 short sensory setae situated distad to trichobothria $e b$ and $e s b$, proximad to trichobothrium $i s b$ in lateral view; base of fixed finger with 9-10sensory setae located proximad to trichobothrium is $b$ in dorsal view $(E m=6-7, M m=2-3, I m=0) ; 2$ short setae located on internal side between trichobothria $e b-e s b$ and $i s b$; base of fixed finger with 1 glandular pore on retrolateral and 3 glandular pores on prolateral surface in lateral view; fixed finger with 3 lyrifissures: one $(f b)$ located slightly proximad to trichobothrium $i b$ and one $(f a)$ located close to base on retrolateral view, and one $(f d)$ located at same level as trichobothria et-it in dorsal view; retrolateral lyrifissures on movable finger $\left(m a_{1}, m a_{2}, m a_{3}\right)$ not distinguished!; fixed finger with 68-70 even, retroconical and contiguous teeth, reaching to slightly proximad of trichobothrium $i b, 4-5$ proximal and 5-6 distal teeth smaller than others, all teeth with dental canal; movable finger with 55-60 teeth, 9-10 triangular and more or less spaced teeth located distad to trichobothrium $t$, other teeth blunt, cusped and becoming flatter to the base, and reaching to slightly proximad to trichobothrium $b$, all teeth with dental canal; nodus ramosus of venom duct in fixed chelal finger situated distinctly distad to et (Fig. 6).
Trichobothriotaxy: fixed finger with 8 and movable finger with 4 trichobothria (Figs. 6-7); fixed finger with trichobothria et, it, est, and ist aggregated in distal fourth of the finger, trichobothrium it located at same level as et, ist located distinctly distad to middle of the finger (TS $=0.78$ $0.79)$, is $b$ on retrolateral face, $i b$ closer to $e s b$ than to $i s b, e s b$ located at same level as $e b$; movable finger with trichobothria $t$ and $s t$ situated in distal half of the finger, trichobothrium $s t$ distinctly closer to $t$ than to $s b$, distance $b-s b$ slightly shorter than $t-s t$, distance $s b$-st distinctly longer than distance $s t-t$.

Legs: brown, distinctly lighter in colour than tergites; smooth; coxa I with short, triangular, chitinous and apically stout and blunt anterolateral process, mediolateral process denticulate (Fig. 8); coxal chaetotaxy: 6-9:6:5-7:6-8; subterminal setae bifid, both rami with minute denticulations; claws of legs I-III simple and symmetric; claws of leg IV symmetric, each claw with one small dorsal accessory tooth (Fig. 9); arolia simple and shorter than claws. Leg I: femur L/D 5.57; patella L/D 4.67; femur 1.39x longer than patella; tibia L/D 6.92-7.33; metatarsus L/D 6.30-7.00; tarsus L/D 6.90. Leg IV (Fig. 10): femur L/D 2.00-2.05; patella L/D 2.66-2.72; femur + patella L/D 4.57-4.65; tibia with a long seta situated proximad to middle $(\mathrm{TS}=0.37-0.38)$, L/D 7.827.86; metatarsus with one tactile seta situated basally (TS $=0.12), \mathrm{L} / \mathrm{D} 5.25$; tarsus with one long tactile seta, either located medially (TS=0.51), L/D 10.00 .

Dimensions (in mm.): $\sigma^{7}$ Body length: $4.20-4.43 \mathrm{~mm}$. Carapace: 1.15-1.18/1.32-1.33. Pedipalp: trochanter 0.94/ 0.38; femur 2.17-2.2/0.36-0.37; patella 1.55-1.65/0.40-0.43; chela (with pedicel) 3.53-3.60/0.69-0.70; chela (without pedicel) 3.33-3.40; hand (with pedicel) L.1.49-1.52; hand (without pedicel) 1.29-1.32; movable finger L. 2.24-2.27. Leg I: femur 1.17/0.21; patella $0.84 / 0.18$; tibia $0.88-0.90$ / $0.12-0.13$; metatarsus $0.63 / 0.09-0.10$; tarsus $0.69 / 0.10$. Leg $I V$ : femur $0.86 / 0.42-0.43$; patella $1.17 / 0.43-0.44$; femur + patella $2.00-2.01$; tibia $1.72-1.73 / 0.22$; metatarsus 0.86 / 0.16 ; tarsus $1.20 / 0.12$. 


\section{Remarks}

On the basis of the pedipalpal femur length (2.00$2.50 \mathrm{~mm}$ ), similar size and shape of chelal teeth in distal half of the fixed chelal finger, the position of notch on the median side of the patella (utmost reaching to distal third of the patellal club), length of the movable chelal finger (longer than chelal hand (with pedicel)), and the entirely smooth pedipalp, this large neobiid species discovered in Russia resembles Neobisium (N.) agnolettii Beier, 1973 from Turkey, N. (N.) artaxerxesi Nassirkhani et al., 2018 from Russia, $N$. (N.) atlasense Leclerc, 1989 from Morocco, N. (N.) elegans Beier, 1939 from Croatia and N. (N.) labinskyi Beier, 1937 from Azerbaijan, Bulgaria, Georgia, Russia, and Turkey.

Neobisium (N.) kovalevskayae sp.n. can be easily separated from all of the mentioned species here-inabove by its morphometric characteristics (Fig. 11), e.g. pedipalpal femur is 5.8-6.1x longer than broad in $N$. (N.) kovalevskayae, while this proportion is $7.1 \mathrm{x}$ for $N$. (N.) agnolettii, 3.8-4.3x for $N$. (N.) artaxerxesi, $8.1 \mathrm{x}$ for $N$. (N.) atlasense, $6.8 \mathrm{x}$ for $N$. (N.) elegans, and 4.5-5.1x for N. (N.) labinskyi.

Moreover, the trichobothriotaxy is the other most important difference between the newly found specimens in Russia and the other close species compared here, e.g. in $N$. (N.) kovalevskayae, trichobothrium ist clearly located very close to the trichobothrial group $e b-i b-e s b$, at the same level as $t$, whereas it is clearly isolated and situated far of the trichobothrial group $e b$ $i b-e s b$, distinctly proximad to $t$, in the other species (see Beier, 1937: fig. 2; Beier, 1939: fig. 36; Beier, 1963: figs 103, 117; Beier, 1973: fig. 3; Heurtault, 1968: fig. 3; Ćurčić, 1988: fig. 80; Ćurčić, 1984: fig. 38; Leclerc, 1989: fig. 4; Petrov, Štáhlavský, 2007 : figs. 9-10; Nassirkhani et al., 2018: figs. 7-8).

Acknowledgments. The authors wish to thank Dr. Reza Vafai Shoushtari for his support, Dr. Ilya Turbanov for his useful comments, and Mr. Mahmoud Nassirkhani for his assistance.

Disclosure Statement. No potential conflict of interest was reported by the authors.

\section{References}

Beier M. 1934. Neue covernicole und subterrane Pseudoscorpione // Mitteilungen über Höhlen und Karstforschung. P.53-59.

Beier M. 1937. Zwei neue Neobisien (Pseudoscorp.) aus dem Kaukasus // Zoologischer Anzeiger. Bd. 117. S.107-109.

Beier M. 1949. Türkische Pseudoscorpione // Revue de la Faculté des Sciences de l'Université d'Istanbul B. Vol.14. S.1-20.

Beier M. 1963. Ordnung Pseudoscorpionidea (Afterskorpione) // d'Aguilar J., Beier M., Franz H., Raw F. (Hrsg.). Bestimmungsbücher zur Bodenfauna Europas. Bd.1. Berlin: AkademieVerlag [in German].

Beier M. 1964. Pseudoskorpione aus dem Bucegi-Gebirge in Rumänien // Zoologischer Anzeiger. Bd.173. S.210-212.

Beier M. 1973. Beiträge zur Pseudoscorpioniden-fauna Anatoliens // Fragmenta Entomologica. Vol.8. S.223-236.
Chamberlin J.C. 1931. The arachnid order Chelonethida // Stanford University Publications, Biological Sciences. Vol.7. No.1. P.1-284.

Ćurčić B.P.M. 1984. The genus Neobisium Chamberlin, 1930 (Neobisiidae, Pseudoscorpiones, Arachnida): on new species from the USSR and the taxonomy of its subgenera // Glasnik Muzeja Srpske Zemlje, Beograd (B). Vol.39. P.124-153.

Ćurčić B.P.M. 1988. Cave-dwelling pseudoscorpions of the Dinaric karst. Ljubljana: Slovenska Akademija Znanosti in Umetnosti. $192 \mathrm{p}$.

Harvey M.S. 1992. The phylogeny and classification of the Pseudoscorpionida (Chelicerata: Arachnida) // Invertebrate Taxonomy. Vol.6. P.1373-1435. https://doi.org/10.1071/IT9921373

Harvey M.S. 2013. Pseudoscorpions of the World, version 3.0. Western Australian Museum, Perth. http://www.museum.wa. gov.au/catalogues/pseudoscorpions (accessed March 13th 2019)

Harvey M.S., Ratnaweera P.B., Udagama P.V., Wijesinghe M.R. 2012. A new species of the pseudoscorpion genus Megachernes (Pseudoscorpiones: Chernetidae) associated with a threatened Sri Lankan rainforest rodent, with a review of host associations of Megachernes // Journal of Natural History. Vol.46. P.2519-2535.

Heurtault J. 1968. Une nouvelle espèce de pseudoscorpion du Gard: Neobisium (N.) vachoni (Neobisiidae) // Bulletin du Muséum National d'Histoire Naturelle, Paris. Vol.40. No.2. P.315-319.

Judson M.L.I. 2007. A new and endangered species of the pseudoscorpion genus Lagynochthonius from a cave in Vietnam, with notes on chelal morphology and the composition of the Tyrannochthoniini (Arachnida, Chelonethi, Chthoniidae) // Zootaxa. Vol.1627. P.53-68

Leclerc P. 1989. Neobisium (N.) atlasense nouvelle espèce de Neobisiidae cavernicole du Maroc (Pseudoscorpions, Arachnides) // Revue Arachnologique. T.8. Fasc.3. P.45-51.

Nassirkhani M., Doustaresharaf M.M. 2018. New records of epigean Neobisium species (Pseudoscorpiones: Neobisiidae) from northwestern Iran // Arachnology. Vol.17. No.8. P.367-374.

Nassirkhani M., Mumladze L. 2019. Neobisium (Neobisium) moreoticum (Pseudoscorpiones: Neobisiidae) from Georgia // Arachnologische Mitteilungen. Vol.57. P.37-42. doi:10.30963/ aramit5707

Nassirkhani M., Snegovaya N., ChumachenkoY.A. 2018. Description of a new epigean Neobisium (Neobisium) species (Pseudoscorpiones: Neobisiidae) and redescription of Neobisium (N.) golovatchi from Russia // Revista Ibérica de Aracnología. Vol.33. P.31-37.

Nassirkhani M., Zamani M. 2017. Two species of the genus Neobisium (Pseudoscorpiones: Neobisiidae) from western Iran // Arachnologische Mitteilungen. Vol.53. P.53-61. doi:10.5431/ aramit5309

Petrov B.P., Štáhlavský F. 2007. New species of pseudoscorpions (Arachnida:Pseudoscorpiones) for the fauna of Bulgaria // Historia naturalis bulgarica. Vol.18. P.15-27.

Sezek F., Özkan M. 2008. Developmental Stages of Neobisium erythrodactylum (Koch, 1873): New to the Turkish Fauna // Turkish Journal of Zoology. Vol.32. P.27-32.

Sezek F., Özkan M. 2011. [Two new records for Pseudoscorpion fauna of Turkey] // Türkiye Entomoloji Dergisi. Vol.35. No.3. P.509-518 [in Turkish].

Zaragoza J.A. 2008. On the status of the subspecies of Roncocreagris galeonuda (Pseudoscorpiones: Neobisiidae): importance of the chelal microsetae pattern. Remarks on the genus Roncocreagris Mahnert // Revista Ibérica de Aracnología. Vol.15. P. 35-46.

Zaragoza J.A. 2017. Revision of the Ephippiochthonius complex (Pseudoscorpiones, Chthoniidae) in the Iberian Peninsula, Balearic Islands and Macaronesia, with proposed changes to the status of the Chthonius subgenera // Zootaxa. Vol.4246. No.1. P.1-221. https://doi.org/10.11646/zootaxa.4246.1.1

Responsible editor K.G. Mikhailov 